\title{
Fosaprepitant and aprepitant: an update of the evidence for their place in the prevention of chemotherapy-induced nausea and vomiting
}

This article was published in the following Dove Press journal:

Core Evidence

24 September 2009

Number of times this article has been viewed

\author{
Patrick Langford' \\ Paul Chrisp ${ }^{2}$ \\ 'Prime Medica Ltd, Knutsford, \\ UK; ${ }^{2}$ Core Medical Publishing, \\ Knutsford, UK; These affiliations \\ were correct at the time the \\ manuscript was prepared
}

Introduction: The selective neurokinin-1 receptor antagonist aprepitant is effective in the treatment of acute and delayed chemotherapy-induced nausea and vomiting (CINV) associated with both moderately and highly emetogenic chemotherapy. Fosaprepitant has been developed as an intravenous prodrug of aprepitant.

Aims: To update the evidence underlying the use of fosaprepitant to prevent CINV.

Evidence review: Aprepitant in combination with a serotonin antagonist and a corticosteroid controls acute and delayed symptoms of CINV in patients receiving moderately to highly emetogenic chemotherapy. Bioequivalence of fosaprepitant with aprepitant has recently been demonstrated, which has led to its inclusion in clinical guidelines for treatment of acute CINV with highly, and some regimens of moderately, emetogenic chemotherapy. Early studies of the clinical efficacy of fosaprepitant have shown improvement over treatment with ondansetron. Both aprepitant and fosaprepitant are well tolerated with most adverse events observed of mild or moderate intensity. Conflicting economic evidence has shown that whilst aprepitant provides an increased quality of life in patients treated for CINV, there are differing views over its absolute cost in relation to standard therapy. The incremental cost-effectiveness ratio of aprepitant, however, appears to lie within acceptable bounds.

Place in therapy: Fosaprepitant and aprepitant are recommended in guidelines for preventing CINV due to moderately and highly emetogenic chemotherapy. Fosaprepitant is bioequivalent to aprepitant, and could offer potential benefits for patients who may be unable to tolerate oral administration of antiemetics during an episode of nausea or vomiting.

Keywords: fosaprepitant, aprepitant, chemotherapy, nausea, vomiting

Core evidence place in therapy summary for fosaprepitant in the prevention of chemotherapy-induced nausea and vomiting

\begin{tabular}{|c|c|c|}
\hline Outcome measure & Evidence & Implications \\
\hline \multicolumn{3}{|l|}{ Pharmacologic evidence } \\
\hline $\begin{array}{l}\text { Bioequivalence of } \\
\text { fosaprepitant }^{\mathrm{a}} \text { with aprepitant }\end{array}$ & Clear & $\begin{array}{l}\text { Fosaprepitant II } 5 \mathrm{mg} \text { is bioequivalent to aprepitant } \\
\text { I } 25 \mathrm{mg} \text { and may be used interchangeably }\end{array}$ \\
\hline \multicolumn{3}{|l|}{ Patient-oriented evidence } \\
\hline $\begin{array}{l}\text { Control of acute and delayed } \\
\text { emesis }\end{array}$ & Clear & $\begin{array}{l}\text { Adding aprepitant to standard antiemetic therapy } \\
\text { with dexamethasone plus a serotonin antagonist } \\
\text { improves control of emesis and reduces need for } \\
\text { rescue medication in patients receiving moderately } \\
\text { or highly emetogenic chemotherapy }\end{array}$ \\
\hline Control of nausea & Clear & $\begin{array}{l}\text { Adding aprepitant to standard antiemetic therapy } \\
\text { with dexamethasone plus a serotonin antagonist } \\
\text { reduces symptoms of nausea in patients receiving } \\
\text { moderately or highly emetogenic chemotherapy }\end{array}$ \\
\hline
\end{tabular}

Correspondence: Patrick Langford 16 City Road,Worsley, Manchester M28 IBD, UK

Email pdlangford@googlemail.com submit your manuscript $\mid$ www.dovepress.com

Dovepress

DOI: $10.2147 /$ CE.S6012 


\begin{tabular}{|c|c|c|}
\hline \multicolumn{3}{|l|}{ (Continued) } \\
\hline Outcome measure & Evidence & Implications \\
\hline- & - & \\
\hline Patient satisfaction & Clear & $\begin{array}{l}\text { Patients more satisfied with their antiemetic } \\
\text { therapy when aprepitant added; less impact of } \\
\text { symptoms on daily activities }\end{array}$ \\
\hline \multicolumn{3}{|l|}{ Economic evidence } \\
\hline Cost effectiveness & Limited & $\begin{array}{l}\text { Acquisition costs of fosaprepitant may be partially } \\
\text { offset by savings in overall direct costs }\end{array}$ \\
\hline
\end{tabular}

\section{Scope, aims, and objectives}

Fosaprepitant (Ivemend ${ }^{\circledR}$, Merck) is a new intravenous prodrug formulation of the oral neurokinin-1 (NK1) receptor antagonist aprepitant (Emend ${ }^{\circledR}$, Merck). Aprepitant blocks the activity of substance $\mathrm{P}$ at NK1 receptors in the brain and has been approved by the US Food and Drug Administration (FDA) for prevention of nausea and vomiting in combination with other antiemetics following moderately or highly emetogenic chemotherapy in patients with cancer.

Fosaprepitant received FDA and European Medicines Agency (EMEA) approval in January 2008 for prevention of acute and delayed nausea and vomiting associated with initial and repeated courses of highly and moderately emetogenic cancer chemotherapy, including high-dose cisplatin, in combination with other antiemetic agents.

The use of an intravenous formulation offers potential benefits for patients who may be unable to tolerate oral administration of antiemetics during an episode of nausea or vomiting. This review assesses the evidence for the use of fosaprepitant and updates the evidence for aprepitant in prophylaxis of acute and delayed chemotherapy-induced nausea and vomiting (CINV).

\section{Methods}

A previous review has conducted a thorough investigation of the use of aprepitant in preventing CINV in the clinical setting up to 2006. ${ }^{1}$ The methodology employed here provides an update to this analysis and also investigates the recent introduction of fosaprepitant as an alternative to aprepitant in the management of CINV.

An English language literature search was conducted on August 8, 2008 in the PubMed database (http://www.ncbi. nlm.nih.gov/entrez) using the search term "fosaprepitant" and limits "Publication Date from July 1, 2006 to July 31, 2008, English."

A total of 80 papers were initially identified. Hand searching to remove articles unrelated to CINV (for example postoperative nausea and vomiting), general overviews of the therapy area, clinical studies where aprepitant or fosaprepitant were not primary investigational drugs, and pharmacokinetic analyses, yielded a total of eight full papers for evaluation (Table 1). Two additional studies were identitfied.

\section{Disease overview}

Nausea and vomiting are a common side effect of chemotherapy, with some drugs such as cisplatin, especially at higher does, causing emesis in most patients. ${ }^{2}$ Avoidance of these symptoms is desirable due to the considerable negative impact of an episode of CINV such as dehydration, impairment of activity and quality of life, and electrolyte imbalance. ${ }^{3}$ More serious consequences of prolonged CINV include organ damage, esophageal tearing, and pneumonia from aspired vomit. ${ }^{3}$ As well as a being a further burden to patients' health and quality of life, CINV can also disrupt

Table I Evidence base include in the review

\begin{tabular}{lll}
\hline Category & \multicolumn{2}{l}{ Number of records } \\
\cline { 2 - 3 } \cline { 2 - 3 } & Full papers & Abstracts \\
\hline Initial search & 80 & 0 \\
Records excluded & 72 & 0 \\
Records included & 8 & 0 \\
Additional studies identified & 2 & 0 \\
Total records included & 10 & 0 \\
Level I clinical evidence (systematic & 1 & 0 \\
review, meta analysis) & & \\
Level 2 clinical evidence (RCT) & 4 & 0 \\
Level $\geq 3$ clinical evidence & & \\
Trials other than RCT & 0 & 0 \\
$\quad$ Case reports & 2 & 0 \\
Economic evidence & 3 &
\end{tabular}

Notes: For definitions of levels of evidence, see Core Evidence website (http://www. dovepress.com/core-evidence-journal).

Abbreviation: RCT, randomized controlled trial. 
and delay chemotherapy schedules. Prevention or alleviation of symptoms can help to minimize these delays allowing patients to continue with their cancer treatment.

CINV is more likely to occur in young, female patients and less likely following alcohol abuse. ${ }^{4}$ The choice of drug is also a major determinant of the severity of CINV with emetogenicity varying widely across available chemotherapeutic agents. ${ }^{5}$

CINV may occur at any of three time points surrounding chemotherapy. Acute CINV is observed within 24 hours of commencing chemotherapy and may last for several hours. It usually presents within 1-2 hours, although with agents such as carboplatin effects may not be seen for up to 10 hours. $^{4}$ A second type, delayed CINV, occurs more than 24 hours after chemotherapy has ended and may continue for a number of days. This can often be worse than an acute episode as the duration may be longer and it is more likely to occur in a patient's home, away from immediate medical assistance. ${ }^{2,4}$ The third and final type is anticipatory CINV, which, as the name suggests, is based on prior negative experiences and occurs before chemotherapy has begun.

Acute and delayed CINV arise through the effect of chemotherapeutic agents acting as noxious stimuli within the body, in turn activating the vomiting center located within the medullary region of the brain and leading to nausea and emesis. It is currently thought that acute CINV is related to activity in peripheral serotoninergic pathways, whereas the action of substance $\mathrm{P}$ at NK1 receptors is responsible for delayed symptoms ${ }^{2,6}$ (Figure 1). Prior experience of CINV can lead to a causal association in some patients between chemotherapy and resultant nausea and emesis, leading to an anticipatory psychologic response prior to subsequent chemotherapy sessions that can be difficult to manage.

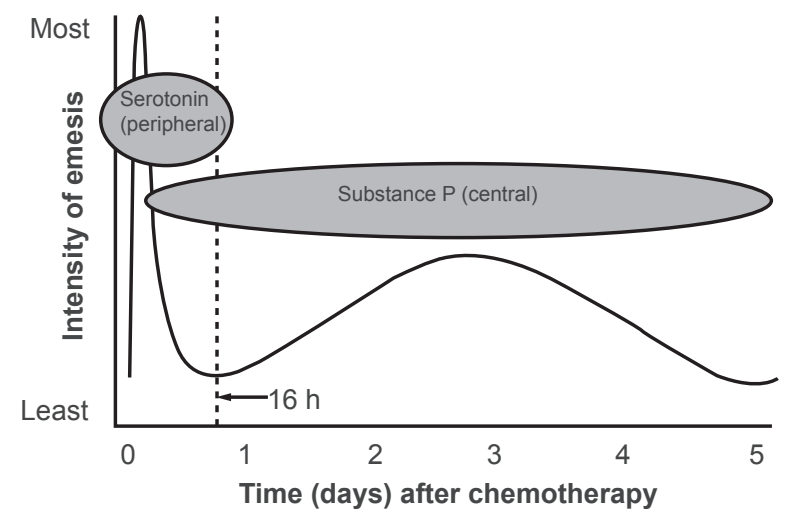

Figure I Proposed mechanism and time course of chemotherapy-induced nausea and vomiting with cisplatin. Copyright (C) 2005, Future Drugs Ltd. Adapted with permission from Aguilar EA, Figueiras MC, Cortes-Funes $\mathrm{H}$, et al. Clinical practice guidelines on antiemetics in oncology. Expert Rev Anticancer Ther. 2005;5(6):963-972.

\section{Current therapy options}

Treatments used in the prophylaxis and control of CINV involve a variety of antiemetic drugs including serotonin receptor antagonists (eg, ondansetron, palonosetron), corticosteroids (eg, dexamethasone), and dopamine antagonists (eg, metoclopramide). The orally administered NK1 receptor antagonist aprepitant is a relatively new addition to the current range of therapy options and has recently been reformulated as the intravenous preparation, fosaprepitant.

Drug treatments are focused primarily on the prevention of acute CINV as this also has the effect of reducing delayed and anticipatory symptoms. ${ }^{4,7}$ A number of clinical, evidencebased guidelines have been produced for the management of CINV (Table 2).

Corticosteroids and serotonin antagonists have been the mainstay of CINV treatment due to highly and moderately emetogenic chemotherapy. Used together these drugs have an efficacy of $60 \%-70 \%$ in patients experiencing acute $\mathrm{CINV}^{8}$ and both classes of drug are well tolerated. ${ }^{2,4,8}$ Augmenting this combination with aprepitant has been proven to be effective in $80 \%-90 \%$ of acute cases of CINV in highly ${ }^{9,10}$ or moderately ${ }^{11}$ emetogenic chemotherapy. Guidelines now approve aprepitant alongside a serotonin antagonist and a corticosteroid for acute and delayed CINV with all forms of highly emetogenic chemotherapy, and the use of these three drugs in combination has a safety profile similar to that of a serotonin antagonist and a corticosteroid., 9

Guidelines do not yet recommend aprepitant therapy for all moderately emetogenic chemotherapeutic regimens. However, for treatment of CINV following an anthracycline plus cyclophosphamide, aprepitant is now suggested in all four major treatment guidelines (Table 2).

For low to moderately emetogenic chemotherapy, corticosteroids alone are effective in up to $90 \%$ of patients. ${ }^{4}$ National Comprehensive Cancer Network (NCCN) guidelines also recommend prochlorperazine or the dopamine antagonist metoclopramide as alternatives to a corticosteroid for the treatment of acute or delayed CINV in chemotherapy with low emetogenic potential. Diphenhydramine can also be coadministered with a dopamine antagonist to counteract the potential for extrapyramidal adverse effects, ${ }^{8}$ however, the use of dopamine antagonists is now recommended only as salvage for patients unresponsive to serotonin antagonists. ${ }^{4}$

\section{Unmet needs}

The introduction of aprepitant into the therapeutic regimen for $\mathrm{CINV}$ has led to considerable improvement in 
Table 2 Evidence-based clinical practice guidelines for the prevention of acute and delayed chemotherapy-induced nausea and vomiting

\begin{tabular}{|c|c|c|c|}
\hline Guideline & Emetogenic potential & Acute CINV & Delayed CINV \\
\hline \multirow[t]{5}{*}{$\mathrm{ASCO}^{15}$} & High & $\begin{array}{l}\text { Serotonin antagonist + dexamethasone } \\
\text { +aprepitant before chemotherapy }\end{array}$ & Dexamethasone + aprepitant \\
\hline & $\begin{array}{l}\text { Moderate: patients receiving } \\
\text { anthracycline + cyclophosphamide }\end{array}$ & $\begin{array}{l}\text { Aprepitant }+ \text { serotonin antagonist } \\
+ \text { dexamethasone before chemotherapy }\end{array}$ & Aprepitant \\
\hline & Moderate & Serotonin antagonist + dexamethasone & $\begin{array}{l}\text { Serotonin antagonist or } \\
\text { dexamethasone }\end{array}$ \\
\hline & Low & Dexamethasone & No routine antiemetic \\
\hline & Minimal & No routine antiemetic & No routine antiemetic \\
\hline \multirow[t]{5}{*}{ ESMO $^{16}$} & High & $\begin{array}{l}\text { Serotonin antagonist }+ \text { corticosteroid } \\
+ \text { aprepitant }\end{array}$ & Corticosteroid + aprepitant \\
\hline & $\begin{array}{l}\text { Moderate: patients receiving } \\
\text { anthracycline }+ \text { cyclophosphamide }\end{array}$ & $\begin{array}{l}\text { Serotonin antagonist }+ \text { dexamethasone } \\
+ \text { aprepitant }\end{array}$ & Dexamethasone or aprepitant \\
\hline & Moderate & Serotonin antagonist + corticosteroid & $\begin{array}{l}\text { Serotonin antagonist or } \\
\text { corticosteroid }\end{array}$ \\
\hline & Low & Single agent, eg, corticosteroid & No routine antiemetic \\
\hline & Minimal & No routine antiemetic & No routine antiemetic \\
\hline \multirow[t]{5}{*}{ MASCC $^{17}$} & High & $\begin{array}{l}\text { Serotonin antagonist }+ \text { dexamethasone } \\
+ \text { aprepitant or fosaprepitant before } \\
\text { chemotherapy }\end{array}$ & Dexamethasone + aprepitant \\
\hline & $\begin{array}{l}\text { Moderate: patients receiving } \\
\text { anthracycline }+ \text { cyclophosphamide }\end{array}$ & $\begin{array}{l}\text { Serotonin antagonist }+ \text { dexamethasone } \\
+ \text { aprepitant or fosaprepitant before } \\
\text { chemotherapy (women specifically) }\end{array}$ & Dexamethasone or aprepitant \\
\hline & Moderate & $\begin{array}{l}\text { Serotonin antagonist }+ \text { dexamethasone in } \\
\text { first course }\end{array}$ & $\begin{array}{l}\text { Dexamethasone or serotonin } \\
\text { antagonist }\end{array}$ \\
\hline & Low & Single agent, eg, corticosteroid & None stated \\
\hline & Minimal & No routine antiemetic & None stated \\
\hline \multirow[t]{5}{*}{$\mathrm{NCCN}^{18}$} & High & $\begin{array}{l}\text { Aprepitant or fosaprepitant }+ \text { serotonin } \\
\text { antagonist }+ \text { dexamethasone } \pm \text { lorazepam } \\
\text { before chemotherapy }\end{array}$ & 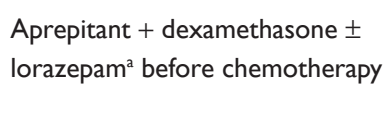 \\
\hline & $\begin{array}{l}\text { Moderate: select patients } \\
\text { receiving cisplatin, carboplatin, } \\
\text { doxorubicin, epirubicin, ifosfamide, } \\
\text { irinotecan, methotrexate }\end{array}$ & $\begin{array}{l}\text { Aprepitant or fosaprepitant }+ \text { serotonin } \\
\text { antagonist }+ \text { dexamethasone } \mathrm{e}^{\mathrm{a}} \text { before } \\
\text { chemotherapy }\end{array}$ & $\begin{array}{l}\text { Aprepitant } \pm \text { dexamethasone } \pm \\
\text { lorazepam }^{\text {a }}\end{array}$ \\
\hline & Moderate & $\begin{array}{l}\text { Serotonin antagonist }+ \text { dexamethasone } \pm \\
\text { lorazepam }^{a}\end{array}$ & $\begin{array}{l}\text { Dexamethasone or serotonin } \\
\text { antagonist } \pm \text { lorazepam }{ }^{\mathrm{a}}\end{array}$ \\
\hline & Low & $\begin{array}{l}\text { Dexamethasone or prochlorperazine or } \\
\text { metoclopramide } \pm \text { lorazepam }{ }^{\mathrm{a}} \text { before } \\
\text { chemotherapy }\end{array}$ & $\begin{array}{l}\text { Dexamethasone or } \\
\text { prochlorperazine or } \\
\text { metoclopramide } \pm \text { lorazepam } \\
\text { before chemotherapy }\end{array}$ \\
\hline & Minimal & No routine antiemetic & No routine antiemetic \\
\hline
\end{tabular}

Note: $\pm \mathrm{H}_{2}$ blocker or proton pump inhibitor.

Abbreviations: ASCO, American Society of Clincal Oncology; CINV, chemotherapy-induced nausea and vomiting; ESMO, European Society for Medical Oncology; MASCC, Multinational Association of Supportive Care in Cancer; NCCN, National Comprehensive Cancer Network.

treatment outcomes for both the acute and delayed phases of CINV. The combination of corticosteroid, serotonin antagonist, and aprepitant has been shown to have up to $90 \%$ efficacy in the prevention of both acute and delayed CINV. ${ }^{9-11}$ However, the current formulation of aprepitant for oral delivery, though highly effective, may not be optimal for all clinical situations.
Oral administration may not always be feasible, such as in patients who are not fully conscious or those who cannot tolerate oral drugs during an episode of nausea and vomiting. In fact, administration of a drug via the oral route may even cause or exacerbate symptoms and emesis shortly after receiving oral aprepitant could result in the loss of some or the whole of the dose. For patients on 
chemotherapy at high risk of oral mucositis, such as those with head and neck cancer, oral formulations may also be unsuitable. An alternative method of administration would help to alleviate these issues.

\section{Rationale for fosaprepitant}

Fosaprepitant received approval from both the FDA and EMEA in January 2008 for the prevention of CINV associated with highly and moderately emetogenic chemotherapy. It is an intravenous prodrug of the orally administered antiemetic aprepitant, the first clinically available NK1 receptor antagonist to be indicated for CINV. The mechanism of action of aprepitant in blocking substance $\mathrm{P}$ activity at NK1 receptors in the brain ${ }^{2,6}$ provides a new means of preventing CINV and offers synergistic improvement in the management of symptoms when used alongside corticosteroids and serotonin antagonists. Patients can now be assured of considerably improved outcomes in the prevention of CINV using these drugs.

As a reformulated prodrug, fosaprepitant avoids the problems associated with oral administration, and when infused intravenously is rapidly converted to active aprepitant by phosphatase enzymes. ${ }^{12,13}$ An investigation by Lasseter and colleagues $^{14}$ demonstrated bioequivalence of fosaprepitant to aprepitant, and consequently the pharmacologic effects of fosaprepitant are the same as, and directly attributable to, aprepitant. Recent revisions to the Multinational Association of Supportive Care in Cancer (MASCC) and NCCN clinical guidelines also support this bioequivalence in advising that the two drugs may be used interchangeably on the first day of intervention for acute CINV associated with highly or moderately emetogenic chemotherapy (Table 2).

\section{Clinical evidence with fosaprepitant}

In reviewing clinical evidence for the use of fosaprepitant in treatment of CINV, it must be remembered that its pharmacologic activity is entirely dependent on its active metabolite, aprepitant. Some early studies of fosaprepitant in the clinical setting are available, however they tend to involve small numbers of patients and do not reflect best practice dose regimens as recommended by current guidelines. Therefore, much of the evidence presented here relates to aprepitant, although outcomes can be considered equally relevant to the efficacy of fosaprepitant.

The literature search conducted for this analysis retrieved evidence available subsequent to the publication of a previous review by Chrisp. ${ }^{1}$ Five further studies on aprepitant were identified that investigated the efficacy of aprepitant for
CINV in both first line ${ }^{11,19,20}$ and salvage therapy, ${ }^{21}$ along with a study of the tolerability of fosaprepitant and bioequivalency to aprepitant. ${ }^{14}$ An early clinical study investigating the use of fosaprepitant ${ }^{22}$ was also identified.

A variety of endpoints are used in the determination of the efficacy of drugs for treatment of CINV. The main indicator of success in studies of these medications tends to be "complete control," which is usually defined as no nausea and no use of rescue medication and forms the basis of much of the analysis of evidence in this review. Other endpoints included measurements of nausea [either percentage of patients experiencing no significant nausea or a subjective assessment by the patient of their own symptoms using a visual analog scale (VAS) from 0 to 100 , with $100=$ worst nausea possible] and the percentage of patients free from emesis.

\section{Bioequivalence of fosaprepitant to aprepitant}

In a randomized, open label, crossover study by Lasseter and colleagues, ${ }^{14}$ an intravenous dose of fosaprepitant $115 \mathrm{mg}$ was shown to have bioequivalence to oral aprepitant $125 \mathrm{mg}$ (Table 3). Following pharmacokinetic analysis, similar absolute values with the two drugs were observed for area under the concentration time curve (AUC), concentration after 24 hours, and half-life. The time to maximum concentration was reached much sooner with fosaprepitant as would be expected for an intravenous formulation. Mean plasma aprepitant concentrations also differed for the first 4 hours postdose, with higher concentrations observed following intravenous fosaprepitant compared with oral aprepitant.

Table 3 Level 2 evidence of the bioequivalence of fosaprepitant to aprepitant

\begin{tabular}{|c|c|c|}
\hline \multirow[t]{2}{*}{ Variable } & \multicolumn{2}{|c|}{ Geometric mean $^{a}$} \\
\hline & $\begin{array}{l}\text { Aprepitant } \\
\text { I } 25 \mathrm{mg}\end{array}$ & $\begin{array}{l}\text { Fosaprepitant } \\
\text { I I5 mg }\end{array}$ \\
\hline$A \cup C_{0-\infty}(\mathrm{ng} \cdot \mathrm{h} / \mathrm{mL})$ & 27759 & 29611 \\
\hline $\mathrm{AUC}_{0-\infty}$ ratio & & 1.13 \\
\hline (fosaprepitant/aprepitant) & & $90 \% \mathrm{Cl}^{\mathrm{b}}: 1.06,1.20$ \\
\hline $\mathrm{C}_{\max }(\mathrm{ng} / \mathrm{mL})$ & 1354 & 3095 \\
\hline $\mathrm{C}_{\max }$ ratio & & 2.47 \\
\hline (fosaprepitant/aprepitant) & & $95 \% \mathrm{Cl}: 2.25,2.7 \mathrm{I}$ \\
\hline $\mathrm{C}_{24 \mathrm{~h}}(\mathrm{ng} / \mathrm{mL})$ & 494 & 504 \\
\hline$t_{\max }(h)^{a}$ & 4.0 & 0.25 \\
\hline$t_{1 / 2}(h)^{a}$ & 14.0 & 13.6 \\
\hline
\end{tabular}

Copyright ( 2007. Adapted with permission from Lasseter KC, Gambale J, Jin B, et al.Tolerability of fosaprepitant and bioequivalency to aprepitant in healthy subjects. J Clin Pharmacol. 2007; 47:834-840.

Notes: ${ }^{2}$ Median for $\mathrm{t}_{\max }$ and harmonic mean for $\mathrm{t}_{1 / 2}{ }^{\mathrm{b}} 95 \% \textrm{Cl}$ not reported.

Abbreviations: AUC, area under the concentration-time curve; C, concentration; $\mathrm{Cl}$, confidence interval; t, time. 
Following this initial period, concentrations remained almost identical in the two dose groups.

Bioequivalence was ultimately determined by calculating the confidence interval for the AUC geometric mean ratio of fosaprepitant to aprepitant (Table 3). Both the $90 \%$ and $95 \%$ confidence interval limits fell within predefined bounds of $0.8,1.25$ and therefore supported the proposed bioequivalence hypothesis.

These findings indicate that the evidence pertaining to aprepitant can be applied directly in evaluating the use of fosaprepitant for managing CINV.

\section{Control of CINV with highly emetogenic chemotherapy}

Two studies of the use of fosaprepitant in the treatment of CINV following cisplatin-based chemotherapy have been conducted. ${ }^{22,23}$ In the study by Cocquyt and colleagues, ${ }^{22} 53$ patients receiving cisplatin-based chemotherapy (50-100 mg/m²) were given fosaprepitant 60 or $100 \mathrm{mg}$ (later standardized to $100 \mathrm{mg}$ for all patients following lack of symptom control at the lower dose) or ondansetron $32 \mathrm{mg}$ on day 1 only and in the absence of any other concomitant medications. Patients receiving fosaprepitant exhibited complete control (no emesis or use of rescue medication) in the acute phase in $37 \%$ of cases, with $48 \%$ of patients experiencing complete symptom control in the delayed phase. This compared to $48 \%$ and $17 \%$ of patients, respectively, in the ondansetron group. Similar results were also observed by Van Belle and colleagues. ${ }^{23}$ In a study of 179 patients receiving chemotherapy with cisplatin $\geq 70 \mathrm{mg} / \mathrm{m}^{2}$, patients receiving fosaprepitant and dexamethasone on day 1 experienced complete control of symptoms in $36 \%$ of cases in the acute phase, with $46 \%$ of patients exhibiting complete control in the delayed phase. In patients who were followed up with aprepitant treatment on days 2-5 following fosaprepitant on day 1 , outcomes were slightly better, with complete control observed in 44 and 59\% of patients in the acute and delayed phases, respectively. In a third treatment group, who received ondansetron and dexamethasone on day 1 , fewer patients (38\%) experienced reduced delayed phase symptom control, however, a greater proportion of patients ( $83 \%$ ) exhibited complete control in the acute phase when compared with both of the fosaprepitant groups.

Although both of these early studies are relatively small and were performed before dosages and combinations had been standardized, they demonstrate marked improvement in the management of CINV symptoms in the delayed phase following treatment with fosaprepitant. However, as the antiemetic drug regimens employed in these trials did not follow current best practice as set out in clinical guidelines, the observed efficacy in general, especially in the acute phase, was relatively low.

As previously described, fosaprepitant activity is directly attributable to its active form aprepitant, with strong evidence supporting the use of aprepitant alongside other antiemetics in preventing nausea and emesis following highly emetogenic chemotherapy with cisplatin $\geq 70 \mathrm{mg} / \mathrm{m}^{2} .{ }^{1}$ Aprepitant administered on day 1 in conjunction with ondansetron and dexamethasone, and followed up with aprepitant and dexamethasone on days 2 and 3, with a final dose of dexamethasone on day 4 , can prevent both emesis and the need for further rescue medication in up to $\sim 90 \%$ of patients in the acute phase and up to $75 \%$ in the delayed phase of CINV.

An additional recent trial ${ }^{19}$ identified by the literature search performed for this review provides further evidence for the efficacy of aprepitant in the treatment of CINV following highly emetogenic chemotherapy. There were no statistically significant differences in complete response observed in both the acute and delayed phases of CINV when aprepitant was given on day 1 in a single-dose regimen with palonosetron and dexamethasone $(66.7 \%$ and $63.0 \%$, respectively), compared with a 3-day aprepitant regimen (70.4\% complete response in the acute phase, $59.3 \%$ in the delayed phase). Outcomes with both of these regimens were considerably better than in the control group of patients receiving palonosetron and dexamethasone (Table 4).

However, it should be noted that the complete response rate in this trial was $\sim 15 \%-20 \%$ lower than in earlier trials that used an alternative serotonin antagonist, ondansetron, in combination with the same dose regimen of aprepitant and dexamethasone. ${ }^{9,10}$ Further studies may be needed to investigate the efficacy of palonosetron in combination with aprepitant for antiemetic treatment in highly emetogenic chemotherapy.

Other outcomes related to incidence of acute and delayed vomiting with aprepitant were favorable, with similarly high emesis prevention rates observed with both the 3-day (92.9\%) and 1-day (92.6\%) aprepitant regimens. Low nausea scores were also reported in both treatment arms (Table 4).

Current evidence therefore remains in support of the use of aprepitant for prevention of acute and delayed CINV in highly emetogenic chemotherapy, and also indicates an equivalent response with 3 day versus 1 day administration of aprepitant.

\section{Control of CINV with moderately emetogenic chemotherapy}

The earlier review by Chrisp $^{1}$ also noted the efficacy of aprepitant for prevention of CINV in moderately 
Table 4 Outcomes achieved with aprepitant in the prevention of CINV due to highly or moderately emetogenic chemotherapy

\begin{tabular}{|c|c|c|c|c|c|c|c|c|c|c|c|}
\hline \multirow[t]{3}{*}{ Emetogenicity } & \multirow{3}{*}{$\begin{array}{l}\text { Level of } \\
\text { evidence }\end{array}$} & \multirow[t]{3}{*}{ Design } & \multirow{3}{*}{$\begin{array}{l}\text { CT } \\
\text { regimen }\end{array}$} & \multirow{3}{*}{$\begin{array}{l}\text { Antiemetic } \\
\text { treatment }\end{array}$} & \multicolumn{6}{|l|}{ Outcome } & \multirow[t]{3}{*}{ Reference } \\
\hline & & & & & \multicolumn{3}{|c|}{ Acute phase } & \multicolumn{3}{|c|}{ Delayed phase } & \\
\hline & & & & & $\begin{array}{l}\text { Complete } \\
\text { response } \\
(\%)^{\mathrm{a}}\end{array}$ & $\begin{array}{l}\text { Emesis } \\
\text { free } \\
(\%)\end{array}$ & Nausea & $\begin{array}{l}\text { Complete } \\
\text { response } \\
(\%)^{\mathrm{a}}\end{array}$ & $\begin{array}{l}\text { Emesis } \\
\text { free }\end{array}$ & Nausea & \\
\hline \multirow[t]{3}{*}{ High } & 2 & $\begin{array}{l}\text { SI, } \\
\text { RPCT, } \\
\text { DB }\end{array}$ & $\begin{array}{l}\text { Cis based } \\
\geq 50 \mathrm{mg} / \mathrm{m}^{2} \\
\text { or } \\
\text { Ant and Cyc } \\
\text { combination, } \\
\text { I cycle }\end{array}$ & $\begin{array}{l}\text { Day I: } \\
\text { Apl25 mg + } \\
\text { Dex I2 mg + } \\
\text { Pal 0.25 mg } \\
\text { Day 2-3: } \\
\text { Ap } 80 \text { mg + } \\
\text { Dex } 8 \text { mg } \\
\text { Day 4: Dex } \\
8 \mathrm{mg}(\mathrm{n}=29)\end{array}$ & 66.7 & 96.4 & $0^{\mathrm{b}}$ & 63.0 & 92.9 & $\begin{array}{ll}\text { Day } 2 & 4^{\mathrm{b}} \\
\text { Day } 3 & 1.5^{\mathrm{b}} \\
\text { Day } 4 & 3.5^{\mathrm{b}} \\
\text { Day } 5 & 0^{\mathrm{b}}\end{array}$ & $\begin{array}{l}\text { Herrington } \\
\text { et al. }{ }^{19}\end{array}$ \\
\hline & & & & $\begin{array}{l}\text { Day I: } \\
\text { Apl25 mg + } \\
\text { Dex I2 mg } \\
+ \text { Pal } \\
0.25 \text { mg } \\
\text { Day 2-3: } \\
\text { Pla + Dex } \\
8 \text { mg } \\
\text { Day 4: Dex } \\
8 \text { mg }(n=30)\end{array}$ & 70.4 & 100 & $0^{\mathrm{b}}$ & 59.3 & 92.6 & $\begin{array}{ll}\text { Day } 2 & \mathrm{I}^{\mathrm{b}} \\
\text { Day } 3 & 2.5^{\mathrm{b}} \\
\text { Day } 4 & 2.5^{\mathrm{b}} \\
\text { Day } 5 & 0^{\mathrm{b}}\end{array}$ & \\
\hline & & & & $\begin{array}{l}\text { Day I: Pla + } \\
\text { Dex } \\
\text { I8 mg + Pal } \\
0.25 \mathrm{mg} \text { Day } \\
\text { 2-3: Pla + } \\
\text { Dex } 8 \mathrm{mg} \\
\text { Day 4: Dex } \\
8 \mathrm{mg}(\mathrm{n}=16)\end{array}$ & 56.2 & 93.8 & $0^{\mathrm{b}}$ & 31.2 & 50 & $\begin{array}{ll}\text { Day } 2 & 0^{\mathrm{b}} \\
\text { Day } 3 & 2.5^{\mathrm{b}} \\
\text { Day } 4 & 2.5^{\mathrm{b}} \\
\text { Day } 5 & 0^{\mathrm{b}}\end{array}$ & \\
\hline Moderate & 3 & $\begin{array}{l}\text { MC, SA, } \\
\text { OL }\end{array}$ & $\begin{array}{l}\text { Car, Epi, Ida, Ifo, } \\
\text { Iri, Mit, or Oxa; } \\
\text { Met }>250 \\
\mathrm{mg} / \mathrm{m}^{2} ; \text { Cyc } \\
<\mathrm{I} 500 \mathrm{mg} / \mathrm{m}^{2} \text {; } \\
\text { Dox }> \\
25 \mathrm{mg} / \mathrm{m}^{2} \text {; } \\
\text { or Cis } \leq \\
50 \mathrm{mg} / \mathrm{m}^{2}\end{array}$ & $\begin{array}{l}\text { Day I: Ap } \\
\text { I } 25 \mathrm{mg}+ \\
\text { Dex I } 2 \mathrm{mg}+ \\
\text { Pal } 0.25 \mathrm{mg} \\
\text { Day 2-3: } \\
\text { Ap } 80 \mathrm{mg}+ \\
\text { Dex } 8 \mathrm{mg} \\
(\mathrm{n}=58)\end{array}$ & 88 & 93 & $7 / c$ & 78 & 93 & $53^{c}$ & $\begin{array}{l}\text { Grote } \\
\text { et al. }{ }^{. \prime}\end{array}$ \\
\hline \multirow[t]{2}{*}{ Moderate } & 2 & $\begin{array}{l}\text { SI, } \\
\text { RPCT, } \\
\text { DB }\end{array}$ & $\begin{array}{l}\text { Dox } \\
60 \mathrm{mg} / \mathrm{m}^{2}+ \\
\text { Cyc } \\
600 \mathrm{mg} / \mathrm{m}^{2}\end{array}$ & $\begin{array}{l}\text { Day I: Ap } \\
\text { I25 mg + } \\
\text { Dex I } 2 \mathrm{mg} \\
\text { + Ond } 8 \mathrm{mg} \\
\text { bid Day 2-3: } \\
\text { Ap } 80 \mathrm{mg} \mathrm{qd}\end{array}$ & 72.1 & 72.1 & $62.3^{c}$ & 64.4 & 75.6 & $47.3^{c}$ & Yeo et al. ${ }^{20}$ \\
\hline & & & & $\begin{array}{l}\text { Day I: Dex } \\
20 \mathrm{mg}+ \\
8 \mathrm{mg} \text { Ond } \\
\text { bid Day 2-3: } \\
\text { Ond } 8 \mathrm{mg} \text { bid }\end{array}$ & 72.6 & 74.2 & $59.7^{c}$ & 57.8 & 67.4 & $59.5^{c}$ & \\
\hline
\end{tabular}

Notes: a Defined as no vomiting or use of rescue medication. ${ }^{b}$ Median VAS score $(0=$ none; $100=$ worst $)$. 'Percentage of patients free from nausea.

Abbreviations: Ant, anthracycline; Ap, aprepitant; bid, twice daily; Car, carboplatin; CINV, chemotherapy-induced nausea and vomiting; Cis, cisplatin; CT, chemotherapy; Cyc, cyclophosphamide; DB, double-blind; Dex, dexamethasone; Dox, doxorubicin; Epi, epirubicin; Ida, idarubicin; Ifo, ifosfamide; Iri, irinotecan; MC, multicenter; Met, methotrexate; Mit, mitoxantrone; OL, open label; Ond, ondansetron; Oxa, oxaliplatin; Pal, palonosetron; Pla, placebo; qd, once daily; RPCT, randomized placebo-controlled trial; SA, single arm; $\mathrm{SI}$, single institution; VAS, visual analog scale. 
emetogenic chemotherapy. A major study showed that a 3-day regimen of aprepitant, together with the serotonin antagonist ondansetron plus dexamethasone on day 1, was able to completely control CINV in $76 \%$ of patients in the acute phase and $55 \%$ in the delayed phase, and more successfully than a regimen of ondansetron and dexamethasone alone. ${ }^{24}$

A more recent study by Grote and colleagues ${ }^{11}$ further supports the use of aprepitant for treatment of nausea and vomiting associated with moderately emetogenic drugs used in chemotherapy. This is the first trial to investigate aprepitant in combination with palonosetron and dexamethasone for treatment of both acute and delayed CINV following moderately emetogenic chemotherapy. The complete response rate was $88 \%$ in the acute phase and $78 \%$ in the delayed phase. These results indicate that this regimen provides effective relief of symptoms (Table 4) and is more effective than a combination of aprepitant and dexamethasone, plus an alternative serotonin antagonist.

Interestingly, the use of palonosetron plus aprepitant appears to be much more effective in the management of CINV in moderately emetogenic chemotherapy compared with the less impressive results described above for highly emetogenic chemotherapy, and is cited by the authors as a potential reason for the considerable improvement in complete response rates. Further reasons for the high efficacy rates observed may also be attributable to the inclusion of patients who had experienced only mild nausea with previous chemotherapy sessions, and a lower proportion of patients receiving the more emetogenic anthracyline/cyclophosphamide combination.

A study has also been conducted to investigate the only moderately emetogenic chemotherapy regimen for which aprepitant-based therapy of CINV has specifically been approved by guidelines. Yeo and colleagues ${ }^{20}$ performed a trial in Chinese patients with breast cancer receiving the chemotherapeutic regimen of doxorubicin and cyclophosphamide. Results indicate that aprepitant has a similar efficacy to standard treatment in the acute phase $(72.1 \%$ versus $72.6 \%$ complete control) but provides greater complete control (64.4\% versus $57.8 \%$ ) and more effective prevention of emesis $(75.6 \%$ versus $67.4 \%)$ in the delayed phase than the standard treatment (Table 4).

These data provide further evidence of the efficacy of aprepitant for CINV prevention following moderately emetogenic chemotherapy.

\section{Salvage therapy}

Aprepitant has also been used as rescue medication in patients for whom standard antiemetic drug combinations have failed to control CINV. A study performed by Oechsle and colleagues ${ }^{21}$ investigated the efficacy of aprepitant as salvage therapy in patients refractory to previous treatment with serotonin antagonists and dexamethasone following a variety of chemotherapy, including cisplatin- (35\%) and anthracyclinebased (30\%) regimens. Addition of aprepitant to the antiemesis treatment schedule led to a decrease in the number of patients suffering from nausea for $>4$ days from $24(71 \%)$ to four $(12 \%)$ $(P<0.001)$, and an increase in the number of patients with no emesis from three $(9 \%)$ to $26(76 \%)(P<0.001)$ (Table 5).

\section{Tolerability}

Aprepitant has been shown to have a safety profile similar to that of nonaprepitant-based antiemetic regimens. ${ }^{1}$ Adverse events are mild and infrequent.

As fosaprepitant is rapidly converted to aprepitant following administration, it would be expected to have similar tolerability to its active metabolite and studies involving fosaprepitant have shown this to be the case. In the trial conducted by Cocquyt and colleagues ${ }^{22}$ fosaprepitant had an equivalent safety profile to the comparator drug ondansetron when used to treat CINV in highly emetogenic chemotherapy, except for an increased incidence of diarrhea (60\% with fosaprepitant versus $9 \%$ with ondansetron). No serious adverse events were considered to be study drug related. Another trial investigating fosaprepitant antiemesis in highly emetogenic chemotherapy also found no significant difference in adverse events versus standard regimens, although an increase in the incidence of diarrhea was again

Table 5 Response to aprepitant salvage therapy; comparison of first chemotherapy cycle with added aprepitant and preceding cycle without aprepitant

\begin{tabular}{|c|c|c|}
\hline \multirow[t]{2}{*}{ Response } & \multicolumn{2}{|l|}{ Patients, $\mathbf{n}$} \\
\hline & Prior to aprepitant & With aprepitant \\
\hline \multicolumn{3}{|c|}{ Nausea, days } \\
\hline $0-1$ & 0 & 18 \\
\hline $2-3$ & 10 & 12 \\
\hline $4-5$ & 16 & 3 \\
\hline$>5$ & 8 & I \\
\hline \multicolumn{3}{|c|}{ Vomiting, , days } \\
\hline 0 & 3 & 26 \\
\hline 1 & 5 & 8 \\
\hline $2-3$ & 18 & 0 \\
\hline$>3$ & 8 & 0 \\
\hline
\end{tabular}


observed (23\% in both fosaprepitant arms versus 5\% in the ondansetron/dexamethasone control group). ${ }^{23}$

These findings were largely in agreement with those from a specific tolerability study. ${ }^{14}$ Fosaprepitant was well tolerated in doses of 90-150 mg; all adverse events were mild or moderate, with headache (3\% in the $115 \mathrm{mg}$ group) and infusion-site pain (10.4\% in the $100 \mathrm{mg}$ group and $7.6 \%$ in the $115 \mathrm{mg}$ dose group) most commonly reported. Vital signs, physical examination, and electrocardiograms showed no sign of being affected by treatment.

Concerns over interactions with other drugs have been investigated, as aprepitant is metabolized by cytochrome P450 (CYP) 3A4 and coadministration with other drugs also metabolized by this enzyme may have clinical significance. The evidence for this is conflicting. One study observed an increase in serious adverse events in patients receiving aprepitant concomitantly with the CYP3A4-metabolized etoposide, vinca alkaloids, and taxanes, compared with those on standard antiemetics. ${ }^{10}$ However, another showed no significant difference in adverse events in patients receiving aprepitant compared with other antiemetics, while receiving chemotherapy with drugs metabolized by CYP3A4 (etoposide, vinorelbine, and paclitaxel). ${ }^{9}$

It is advisable to avoid potential interactions in the absence of conclusive evidence and further guidance is provided in the Dosage, administration, and formulation section.

\section{Economic evidence}

Two recent studies have compared the cost-effectiveness ratio of an antiemetic regimen of aprepitant in combination with a serotonin antagonist and a corticosteroid, with a conventional regimen consisting of a serotonin antagonist and a corticosteroid for CINV treatment in highly emetogenic chemotherapy. ${ }^{25,26}$ Each of the regimens was assessed in models based on published data from major phase III trials in patients receiving chemotherapy with cisplatin. ${ }^{9,28}$

Moore and colleagues ${ }^{26}$ created a Markov model with a 28-day cycle length in which 5 cycles of chemotherapy were modeled (Table 6). Within the model, patients could experience one of four health states: 1) neither acute nor delayed CINV; 2) acute CINV only; 3) delayed CINV only; or 4) both acute and delayed CINV. Each category of outcome was assigned a "healthy day equivalent" (HDE) value (the number of days of optimal health considered equivalent to the time spent in the various health states as assessed by patients themselves). Published clinical trial data ${ }^{9}$ were used to establish probabilities for these outcomes, and costs (reported in 2005 US dollars) were calculated from the payer perspective.
Data were analyzed to estimate the number of HDEs during the 5 cycles of chemotherapy, which was converted to quality-adjusted life-years (QALY) for cost-utility analysis. The incremental cost-effectiveness ratio (ICER), namely the cost per QALY gained with aprepitant in combination with ondansetron plus dexamethasone, over a regimen of ondansetron and dexamethasone only was then calculated and was estimated to be \$US97,429 over a period of five chemotherapy cycles.

Lordick and colleagues ${ }^{25}$ conducted a similar, extensive analysis looking at the cost effectiveness of aprepitant based on a pooled analysis ${ }^{27}$ of two trials in patients receiving antiemetic prophylaxis for highly emetogenic chemotherapy. A model of health states was constructed based on clinical endpoints in the clinical trials: complete protection (no emesis, no rescue therapy, maximum nausea $<25 \mathrm{~mm}$ on a $100 \mathrm{~mm}$ VAS); complete response at best (no emesis, no rescue therapy, maximum nausea $\geq 25 \mathrm{~mm}$ on a $100 \mathrm{~mm}$ VAS); and incomplete response (complement of the preceding states: some emesis or rescue therapy). These states were then assigned utilities (ie, preferences the individual has for a particular health outcome) on a scale of 0 to 1 . Complete protection was graded as 0.9 , complete response at best as 0.7 , and incomplete response as 0.2 . In conjunction with the recorded number of days spent in each health state for each patient, the utility values were used to calculate number of quality-adjusted life-days at the end of 5 days of chemotherapy, which was then extrapolated to arrive at a clinicaleffectiveness measure in terms of QALY (Table 6).

In this analysis, the ICER was estimated at $€ 28,891$ (undiscounted year 2004 euros) over a period of one 5-day chemotherapy cycle.

Although a cost per QALY threshold has not yet been set in Germany where this study originated, aprepitant appears to represent acceptable value in the context of thresholds in other countries such as the $£ 30,000$ put forward by the National Institute for Health and Clinical Excellence. ${ }^{28}$

In terms of cost-effectiveness thresholds, the ICER arrived at by Moore and colleagues ${ }^{26}$ of \$US97,429 is almost twice as much as the commonly applied figure of \$US50,000 used to assess the cost effectiveness of new therapies in the US. ${ }^{29,30}$ However, this was defined in the 1970s and is based on end-stage renal disease treatment, the cost of which is now believed to be more than \$US120,000. ${ }^{31}$ Therefore, the cost of aprepitant treatment may be considered reasonable using this higher threshold.

A third economic analysis ${ }^{32}$ has recently found that an aprepitant-based regimen in both highly and moderately 
Table 6 Economic evidence from three cost effectiveness analyses of aprepitant versus standard therapy in treatment of CINV

\begin{tabular}{|c|c|c|c|c|c|c|c|c|c|}
\hline Treatment & $\begin{array}{l}\text { Duration of } \\
\text { assessment } \\
\text { period }\end{array}$ & $\begin{array}{l}\text { Chemotherapy } \\
\text { regimen }\end{array}$ & $\begin{array}{l}\text { Drug } \\
\text { costs per } \\
\text { regimen } \\
\text { per cycle }\end{array}$ & $\begin{array}{l}\text { Total } \\
\text { costs }\end{array}$ & $\begin{array}{l}\text { Days of } \\
\text { health } \\
\text { gained }\end{array}$ & $\begin{array}{l}\text { QALYs } \\
\text { gained }\end{array}$ & CER & $\begin{array}{l}\text { ICER of } \\
\text { aprepitant } \\
\text { regimen }\end{array}$ & Reference \\
\hline $\begin{array}{l}\text { Ap regimen } \\
\text { Day I: } \\
\text { Ond } 32 \mathrm{mg}+\text { Dex } \\
12 \mathrm{mg}+\text { Ap I } 25 \mathrm{mg}\end{array}$ & $\begin{array}{l}\text { One 5-day cycle of } \\
\text { chemotherapy }\end{array}$ & $\begin{array}{l}\text { HEC } \\
\left(\text { Cis }>70 \mathrm{mg} / \mathrm{m}^{2}\right)\end{array}$ & $€ 225.05$ & $€ 380.04^{\mathrm{a}}$ & $3.53^{\mathrm{a}}$ & $0.0097^{a}$ & NR & $€ 28891^{a}$ & $\begin{array}{l}\text { Lordick } \\
\text { et } \mathrm{al}^{25} \\
\text { (Based on } \\
\text { de Wit } \\
\text { et } \mathrm{a}^{27} \text { ) }\end{array}$ \\
\hline
\end{tabular}

Day 2-3:

Ap $80 \mathrm{mg}+$ Dex $8 \mathrm{mg}$

Day 4:

Dex $8 \mathrm{mg}(\mathrm{n}=5 \mathrm{|})$

Control regimen

$€ 151.67 \quad € 330.44^{\mathrm{a}} \quad 2.90^{\mathrm{a}} \quad 0.0080^{\mathrm{a}} \quad$ NR

Day I:

Ond $32 \mathrm{mg}+$ Dex $20 \mathrm{mg}$

Day 2-4:

Dex $8 \mathrm{mg}$ bid

$(n=518)$

Ap regimen

Day I:

Five cycles of HEC

$\mathrm{HEC}$
$\left(\mathrm{Cis} \geq 70 \mathrm{mg} / \mathrm{m}^{2}\right)$

\$US318.02 \$US1393

$0.040^{\mathrm{b}} \$$ SUS34825 $^{\mathrm{b}}$ \$US97429 ${ }^{\mathrm{b}}$ Moore

chemotherapy $\quad\left(\right.$ Cis $\geq 70 \mathrm{mg} / \mathrm{m}^{2}$ )

Ond $32 \mathrm{mg}+$

Dex 12 mg +Ap I25 mg

Day 2-3:

Ap $80 \mathrm{mg}+$ Dex $8 \mathrm{mg}$

Day 4:

Dex $8 \mathrm{mg}$

Control regimen

Day I:

Ond $32 \mathrm{mg}+$ Dex

$20 \mathrm{mg}$

Day 2-4:

Dex $8 \mathrm{mg}$ bid

(hypothetical cohort

of patients)

Ap regimen:

Day I:

Ap $125 \mathrm{mg}+$ Ond

$32 \mathrm{mg}+\operatorname{Dex} 12 \mathrm{mg}$

Day 2-3:

Ap $80 \mathrm{mg}+$ Dex $8 \mathrm{mg}$

Multiple cycles

HEC
$\left(\right.$ Cis $\left.\geq 70 \mathrm{mg} / \mathrm{m}^{2}\right)$

NR

$0.142^{\mathrm{c}} \quad \mathrm{NR}$

Ap

based:

NR

$\begin{array}{ll}€ 605^{\mathrm{c}} \\ & \text { Real life } \\ & \text { based: }\end{array}$

$\begin{array}{ll} & € 605^{\circ} \\ & \text { Real life } \\ & \text { based: }\end{array}$

dominant

et $\mathrm{a}^{26}$

(Based on

Hesketh

et $\mathrm{al}^{9}$ )

Day 4: Dex $8 \mathrm{mg}$

( $\mathrm{n}=484$ in total)

Control regimen

Day I:

Ond $32 \mathrm{mg}+$ Dex

$20 \mathrm{mg}$ Day 2-4: Ond

$8 \mathrm{mg}$ bid + Dex

$8 \mathrm{mg}$ bid

Ap regimen

Day I:

Ap $125 \mathrm{mg}+$ Ond

$8 \mathrm{mg}+$ Dex $12 \mathrm{mg}$

before chemotherapy

and Ond $8 \mathrm{mg}$

$€ 554^{c}$

after $8 \mathrm{~h}$

\begin{tabular}{|c|c|c|c|c|c|}
\hline & NR & $\begin{array}{l}\text { Trial } \\
\text { based: } \\
€ 67 I^{c} \\
\text { Real life } \\
\text { based: } \\
€ 629^{\circ}\end{array}$ & NR & $0.139^{c}$ & NR \\
\hline MEC (Сус & NR & Trial & NR & $0.133^{c}$ & NR \\
\hline $750-1500 \mathrm{mg} / \mathrm{m}^{2}$ & & based: & & & \\
\hline alone or Cyc & & $€ 348^{c}$ & & & \\
\hline $500-1500 \mathrm{mg} / \mathrm{m}^{2}+$ & & Real life & & & \\
\hline Dox $\leq 60 \mathrm{mg} / \mathrm{m}^{2}$ & & based: & & & \\
\hline or Epi & & $€ 392^{c}$ & & & \\
\hline$\left.\leq 100 \mathrm{mg} / \mathrm{m}^{2}\right)$ & & & & & \\
\hline
\end{tabular}

(Continued) 
Table 6 (Continued)

\begin{tabular}{|c|c|c|c|c|c|c|c|c|c|}
\hline Treatment & $\begin{array}{l}\text { Duration of } \\
\text { assessment } \\
\text { period }\end{array}$ & $\begin{array}{l}\text { Chemotherapy } \\
\text { regimen }\end{array}$ & $\begin{array}{l}\text { Drug } \\
\text { costs per } \\
\text { regimen } \\
\text { per cycle }\end{array}$ & $\begin{array}{l}\text { Total } \\
\text { costs }\end{array}$ & $\begin{array}{l}\text { Days of } \\
\text { health } \\
\text { gained }\end{array}$ & $\begin{array}{l}\text { QALYs } \\
\text { gained }\end{array}$ & CER & $\begin{array}{l}\text { ICER of } \\
\text { aprepitant } \\
\text { regimen }\end{array}$ & Reference \\
\hline Control regimen & & & NR & Trial & NR & $0.119^{c}$ & NR & & \\
\hline Day I: & & & & based: & & & & & \\
\hline Ond $8 \mathrm{mg}+$ Dex & & & & $€ 366^{\circ}$ & & & & & \\
\hline $20 \mathrm{mg}+\mathrm{Pla}$ before & & & & Real life & & & & & \\
\hline chemotherapy and & & & & based: & & & & & \\
\hline Ond $8 \mathrm{mg}$ after $8 \mathrm{~h}$ & & & & $€ 4 \mid 4^{c}$ & & & & & \\
\hline \multicolumn{10}{|l|}{ Day 2-3: Ond } \\
\hline $8 \mathrm{mg}$ bid $(n=428)$ & & & & & & & & & \\
\hline
\end{tabular}

Notes: aPer 5-day cycle of chemotherapy. ${ }^{\text {PPer }} 5$ cycles of chemotherapy. ${ }^{\text {Per }}$ patient.

Abbreviations: Ap, aprepitant; bid, twice daily; CER, cost-effectiveness ratio; CINV, chemotherapy-induced nausea and vomiting; Cis, cisplatin; Cyc, cyclophosphamide; Dex, dexamethsone; Epi, epirubicin; HEC; highly emetogenic chemotherapy; ICER, incremental cost-effectiveness ratio; MEC; moderately emetogenic chemotherapy; NR, not reported; Ond, ondansetron; Pla, placebo; QALY, quality-adjusted life-year.

emetogenic chemotherapy is not only more effective, but also less expensive than standard therapy.

This study utilized two scenarios for highly and moderately emetogenic chemotherapies: one scenario was based on two clinical studies, ${ }^{33,34}$ the second on a real world clinical setting in Belgium. In this analysis only two health states were considered: complete response at best, and incomplete response, which were weighted as 0.7 and 0.2 , respectively, in line with the protocol used by Lordick and colleagues. ${ }^{25}$ Costs were considered from a payer perspective and were reported in year 2005 Euros. The overall costs included both the expenditure on preventative study drugs and also the cost of CINV-related treatment such as rescue medication and hospitalization. In the "real life" situation, differences between medications administered during the trial and doses actually administered during normal clinical practice were taken into account.

Results are presented in Table 6 and demonstrate the cost effectiveness of aprepitant regimens. Compared with standard antiemetic therapy, aprepitant was associated with a gain of 0.003 QALYs and per patient savings of $€ 66.84$ (trial scenario) and $€ 74.62$ ("real life" scenario) in highly emetogenic chemotherapy. The corresponding values in moderately emetogenic chemotherapy were $€ 0.014, € 17.95$, and $€ 21.70$.

It should be noted that all the economic analyses conducted so far have been on studies with aprepitant. Although bioequivalent, the intravenous formulation of fosaprepitant will affect its cost effectiveness. For example, it must be reconstituted in solution from a powder, requires equipment and skilled personnel for its administration, and has the potential for adverse effects such as infusion-site reactions, all of which have the potential to increase costs.
Further studies would therefore be welcome to investigate the cost effectiveness of fosaprepitant-based regimens.

\section{Resource utilization}

CINV is a considerable burden on the resources of health care providers. In a European study, across 208 cycles of moderately to highly emetogenic chemotherapy, the total cost of CINV prophylaxis and treatment was $€ 53.62 .{ }^{35}$ In the US, costs are even higher; an office-based oncologist treating an episode of CINV incurred estimated labor costs of \$US175. ${ }^{36}$ However, costs can be reduced through the prophylaxis of CINV. A study analyzing resources utilized in the hypothetical treatment of 1000 patients with aprepitant plus standard antiemetics found that savings in overall medical resource costs would offset any increase in costs due to the addition of aprepitant by $58.7 \% .^{37}$

A more indepth economic analysis has now confirmed these findings. Lordick and colleague ${ }^{25}$ deduced that the total treatment cost (expenditure on antiemetic drugs plus other health care resources) of aprepitant in a 4-day combination regimen with ondansetron and dexamethasone was $€ 380.04$ per patient; an increase of $€ 49.60$ over standard treatment with ondansetron and dexamethsone only. Aprepitant accounted for $€ 85.92$ of the total treatment cost, and thus the cost offset due to aprepitant was $€ 36.32$ (42\%). Cost offsets were largely as a result of reduced health care resource utilization with the aprepitant regimen ( $€ 154.99$ per patient versus $€ 178.77$ with standard therapy), where savings mainly arose from lower doses of dexamethasone ( $€ 12.54)$, decreased use of rescue medication (€7.38), and less hospitalization (€15.86).

Further savings could be made through changes in the dose frequency of aprepitant. Evidence for the equivalent efficacy 
of 1-day versus 3-day aprepitant in highly emetogenic chemotherapy has been demonstrated, ${ }^{19}$ with associated potential reduction in medication costs. This, however, needs further confirmation.

\section{Patient group/population}

Fosaprepitant is approved for use in the prevention of acute and delayed nausea and vomiting associated with initial and repeated courses of highly and moderately emetogenic cancer chemotherapy, including high-dose cisplatin, in combination with other antiemetic agents. ${ }^{38}$ Recent updates to the MASCC and NCCN guidelines now incorporate fosaprepitant as a recommended alternative to aprepitant in frontline therapy for acute phase CINV in patients receiving highly emetogenic chemotherapy, and also for those patients receiving an anthracycline plus cyclophosphamide. The NCCN also supports the use of fosaprepitant in a further select group of patients receiving cisplatin, carboplatin, doxorubicin, epirubicin, ifosfamide, irinotecan, and methotrexate, for acute CINV only and as an alternative to aprepitant (Table 2).

\section{Dosage, administration, and formulations}

Fosaprepitant (115 mg) may be substituted for aprepitant (125 mg) on day 1 only of the antiemetic drug regimen and should be given prior to chemotherapy as a 15-min infusion. The drug is available as a soluble powder that should be reconstituted in solutions of proven compatibility, and is incompatible with solutions containing divalent cations (eg, $\mathrm{Ca}^{2+}, \mathrm{Mg}^{2+}$ ) including lactated Ringer's solution and Hartmann's solution. ${ }^{38}$ Fosaprepitant should not be administered as a bolus, nor should it be administered intramuscularly or subcutaneously. No dosage adjustment is necessary for the elderly, patients with renal insufficiency or end-stage renal disease undergoing hemodialysis, or patients with mild-to-moderate hepatic insufficiency.

The action of aprepitant as a CYP3A4 inhibitor and inducer means it should not be concomitantly administered with pimozide, terfenadine, astemizole, or cisapride. Aprepitant should also be used with caution in patients receiving any other medications that are either metabolized through, act as substrates for, or inhibit or induce CYP3A4. These include ergot alkaloid derivatives and St John's wort. Coadministration of aprepitant and irinotecan should also be approached with caution as increased toxicity may result from this combination.

Patients on chronic warfarin therapy should have their international normalized ratio of prothrombin time closely monitored for 2 weeks after a 3-day fosaprepitant/aprepitant regimen, and patients using hormonal contraception should switch to an alternative method during and for two months after the last dose of treatment with fosaprepitant or aprepitant.

The dose of corticosteroid administered with fosaprepitant for antiemesis should be adjusted in the same way as aprepitant regimens. This includes a reduction of $50 \%$ in the dose of dexamethasone and oral methylprednisolone, and a $25 \%$ reduction of intravenous methylprednisolone.

\section{Place in therapy}

The NK1 receptor antagonist aprepitant is now established as a frontline treatment in combination with other antiemetic medications for CINV in highly and some types of moderately emetogenic chemotherapy. Guidelines issued by the American Society of Clinical Oncology (ASCO), European Society for Medical Oncology (ESMO), MASCC, and NCCN (Table 2) now recommend it for the management of CINV in all types of highly emetogenic chemotherapy, and a subset of moderately emetogenic chemotherapies using an anthracycline plus cyclophosphamide.

Fosaprepitant is a recently approved intravenous prodrug of aprepitant that has been shown to be bioequivalent. As an intravenous formulation, fosaprepitant offers potential benefits for patients who may be unable to tolerate oral medication during periods of nausea and emesis. Based on the clear evidence of aprepitant's efficacy, fosaprepitant has now been included in guidelines for administration interchangeably with aprepitant on the first day of treatment with highly and some forms of moderately emetogenic chemotherapy for management of acute CINV. Studies with fosaprepitant have also demonstrated success in the treatment of delayed symptoms of CINV that may be an avenue for further investigation, as guidelines do not currently recommend it for this indication.

Economic evidence suggests that the increased costs of aprepitant-based treatment regimens can be partially offset by savings made in other health care resources, with some findings stating that absolute costs with an aprepitant regimen are in fact less than with standard therapy. Some data indicate that further savings could also be made by giving aprepitant on the first day only of a course of CINV treatment as opposed to currently recommended administration over the first 3 days. However, it should be noted that, as an intravenous formulation, additional costs may be associated with the use of fosaprepitant.

A large body of evidence for the clinical efficacy of aprepitant is now well established, and results from new studies 
continue to support its place in the treatment of CINV. The bioequivalence of fosaprepitant to aprepitant along with initial clinical trials indicate the potential of fosaprepitant as a further key component in the management of CINV. Further studies will help to supplement current evidence, particularly by firmly establishing successful treatment outcomes following incorporation of fosaprepitant into the recently updated guidelines for acute CINV, and by continuing to investigate its clinical potential in the delayed phase.

In summary, fosaprepitant is a useful addition to the range of treatment options now available for CINV therapy associated with moderately or highly emetogenic chemotherapy. It has all the key benefits of aprepitant whilst providing a more convenient route of administration for patients who may struggle to tolerate oral medication.

\section{Acknowledgments}

The authors declare that they have no conflict of interests.

\section{References}

1. Chrisp P. Aprepitant: the evidence for its place in the prevention of chemotherapy-induced nausea and vomiting. Core Evidence. 2007;2:15-30.

2. Aguilar EA, Figueiras MC, Cortes-Funes H, et al. Clinical practice guidelines on antiemetics in oncology. Expert Rev Anticancer Ther. 2005;5:963-972.

3. Bender CM, McDaniel RW, Murphy-Ende K, et al. Chemotherapyinduced nausea and vomiting. Clin J Oncol Nurs. 2002;6:94-102.

4. Markman M. Progress in preventing chemotherapy-induced nausea and vomiting. Cleve Clin J Med. 2002;69:609-610, 612, 615-617.

5. Herrstedt J, Aapro MS, Roila F, Kataja VV; ESMO Guidelines Task Force. ESMO minimum clinical recommendations for prophylaxis of chemotherapy-induced nausea and vomiting (NV). Ann Oncol. 2005;16(Suppl 1):i77-i79.

6. Kris MG, Hesketh PJ, Herrstedt J, et al. Consensus proposals for the prevention of acute and delayed vomiting and nausea following highemetic-risk chemotherapy. Support Care Cancer. 2005;13:85-96.

7. Gralla RJ, Osoba D, Kris MG, et al. Recommendations for the use of antiemetics: evidence-based, clinical practice guidelines. J Clin Oncol. 1999;17:2971-2994.

8. Viale PH. Integrating aprepitant and palonosetron into clinical practice: a role for the new antiemetics. Clin J Oncol Nurs. 2005;9:77-84.

9. Hesketh PJ, Grunberg SM, Gralla RJ, et al. The oral neurokinin-1 antagonist aprepitant for the prevention of chemotherapy-induced nausea and vomiting: a multinational, randomized, double-blind, placebo-controlled trial in patients receiving high-dose cisplatin the Aprepitant Protocol 052 Study Group. J Clin Oncol. 2003;21: 4112-4119.

10. Poli-Bigelli S, Rodrigues-Pereira J, Carides AD, et al; Aprepitant Protocol 054 Study Group. Addition of the neurokinin 1 receptor antagonist aprepitant to standard antiemetic therapy improves control of chemotherapy-induced nausea and vomiting. Results from a randomized, double-blind, placebo-controlled trial in Latin America. Cancer. 2003;97:3090-3098.

11. Grote T, Hajdenberg J, Cartmell A, Ferguson S, Ginkel A, Charu V. Combination therapy for chemotherapy-induced nausea and vomiting in patients receiving moderately emetogenic chemotherapy: palonosetron, dexamethasone, and aprepitant. J Support Oncol. 2006;4: 403-408.
12. Huskey SE, Luffer-Atlas D, Dean BJ, McGowan EM, Feeney WP, Chiu SH. Substance $\mathrm{P}$ receptor antagonist I: conversion of phosphoramidate prodrug after i.v. administration to rats and dogs. Drug Metab Dispos. 1999;27:1367- 1373.

13. Hale JJ, Mills SG, MacCoss M, et al. Phosphorylated morpholine acetal human neurokinin-1 receptor antagonists as water-soluble prodrugs. J Med Chem. 2000;43:1234-1241.

14. Lasseter KC, Gambale J, Jin B, et al. Tolerability of fosaprepitant and bioequivalency to aprepitant in healthy subjects. J Clin Pharmacol. 2007; $47: 834-840$.

15. Kris MG, Hesketh PJ, Somerfield MR, et al. American Society of Clinical Oncology guideline for antiemetics in oncology: update 2006. J Clin Oncol. 2006;24:2932-2947.

16. Herrstedt J, Roila F; ESMO Guidelines Working Group. Chemotherapyinduced nausea and vomiting: ESMO clinical recommendations for prophylaxis. Ann Oncol. 2008;19(Suppl 2):ii110-ii112.

17. MASCC (Multinational Association for Supportive Care in Cancer). Antiemetic guideline consensus. 2008. Available at: http://data. memberclicks.com/site/mascc/MASCC_Guidelines_Update.pdf Accessed August 20, 2008.

18. NCCN (National Comprehensive Cancer Network). Clinical practice guidelines in oncology. Antiemesis. v.3. 2009. Available at: http://www. nccn.org/professionals/physician_gls/PDF/antiemesis.pdf. Accessed August 20, 2008.

19. Herrington JD, Jaskiewicz AD, Song J. Randomized, placebocontrolled, pilot study evaluating aprepitant single dose plus palonosetron and dexamethasone for the prevention of acute and delayed chemotherapy-induced nausea and vomiting. Cancer. 2008;112: 2080-2087.

20. Yeo W, Mo FK, Suen JJ, et al. A randomized study of aprepitant, ondansetron and dexamethasone for chemotherapy-induced nausea and vomiting in Chinese breast cancer patients receiving moderately emetogenic chemotherapy. Breast Cancer Res Treat. 2009;113:529-535.

21. Oechsle K, Müller MR, Hartmann JT, Kanz L, Bokemeyer C. Aprepitant as salvage therapy in patients with chemotherapy-induced nausea and emesis refractory to prophylaxis with 5-HT(3) antagonists and dexamethasone. Onkologie. 2006;29:557-561.

22. Cocquyt V, Van Belle S, Reinhardt RR, et al. Comparison of L-758,298, a prodrug for the selective neurokinin-1 antagonist, L-754,030, with ondansetron for the prevention of cisplatin-induced emesis. Eur $J$ Cancer. 2001;37:835-842.

23. Van Belle S, Lichinitser MR, Navari RM, et al. Prevention of cisplatininduced acute and delayed emesis by the selective neurokinin-1 antagonists, L-758,298 and MK-869. Cancer. 2002;94:3032-3041.

24. Warr DG, Hesketh PJ, Gralla RJ, et al. Efficacy and tolerability of aprepitant for the prevention of chemotherapy-induced nausea and vomiting in patients with breast cancer after moderately emetogenic chemotherapy. J Clin Oncol. 2005;23:2822-2830.

25. Lordick F, Ehlken B, Ihbe-Heffinger A, et al. Health outcomes and cost-effectiveness of aprepitant in outpatients receiving antiemetic prophylaxis for highly emetogenic chemotherapy in Germany. Eur $J$ Cancer. 2007;43:299-307.

26. Moore S, Tumeh J, Wojtanowski S, Flowers C. Cost-effectiveness of aprepitant for the prevention of chemotherapy-induced nausea and vomiting associated with highly emetogenic chemotherapy. Value Health. 2007;10:23-31.

27. de Wit R, Herrstedt J, Rapoport B, et al. Addition of the oral NK1 antagonist aprepitant to standard antiemetics provides protection against nausea and vomiting during multiple cycles of cisplatin-based chemotherapy. J Clin Oncol. 2003;21:4105-4111.

28. NICE (National Institute for Health and Clinical Excellence). Measuring effectiveness and cost effectiveness: the QALY. 2007. Available at: http:/ www.nice.org.uk/newsroom/features/measuringeffectivenessandcosteffectivenesstheqaly.jsp Accessed August 20, 2008.

29. Gold MR. Cost-effectiveness in health and medicine. New York: Oxford University Press. 1996. 
30. Garber AM, Phelps CE. Economic foundations of cost-effectiveness analysis. J Health Econ. 1997;16:1-31.

31. Goldman L. Cost-effectiveness in a flat world-can ICDs help the United States get rhythm? N Engl J Med. 2005;353:1513-1515.

32. Annemans L, Strens D, Lox E, Petit C, Malonne H. Cost-effectiveness analysis of aprepitant in the prevention of chemotherapy-induced nausea and vomiting in Belgium. Support Care Cancer. 2008;16:905-915.

33. Herrstedt J, Muss HB, Warr DG, et al; Aprepitant Moderately Emetogenic Chemotherapy Study Group. Efficacy and tolerability of aprepitant for the prevention of chemotherapy-induced nausea and emesis over multiple cycles of moderately emetogenic chemotherapy. Cancer. 2005;104:1548-1555.

34. Schmoll HJ, Aapro MS, Poli-Bigelli S, et al. Comparison of an aprepitant regimen with a multiple-day ondansetron regimen, both with dexamethasone, for antiemetic efficacy in high-dose cisplatin treatment. Ann Oncol. 2006;17:1000-1006.
35. Ihbe-Heffinger A, Ehlken B, Bernard R, et al. The impact of delayed chemotherapy-induced nausea and vomiting on patients, health resource utilization and costs in German cancer centers. Ann Oncol. 2004; 15:526-536.

36. Vanscoy GJ, Fortner B, Smith R, Weber R, Rihn TL. Preventing chemotherapy-induced nausea and vomiting: the economic implications of choosing antiemetics. Community Oncol. 2005;2:127-132.

37. Bell CF, Foley KA, Pelissier JM, Hu HX, Markson LE, Berger ML. Cost consequence model: assessing the use of aprepitant vs. standard anti-emetic therapy in cancer patients undergoing highly emetogenic chemotherapy. Support Care Cancer. 2004;12. Abstract 17.

38. Anon. Ivemend Prescribing Information. Available at: http://www.merck. com/product/usa/pi_circulars/e/emend_iv/emend_iv_pi.pdf. Accessed August 20, 2008.

\section{Core Evidence}

\section{Publish your work in this journal}

Core Evidence is an international, peer-reviewed open-access journal evaluating the evidence underlying the potential place in therapy of drugs throughout their development lifecycle from preclinical to postlaunch. The focus of each review is to evaluate the case for a new drug or class in outcome terms in specific indications and patient

\section{Dovepress}

groups. The manuscript management system is completely online and includes a very quick and fair peer-review system, which is all easy to use. Visit http://www.dovepress.com/testimonials.php to read real quotes from published authors. 